\title{
MODELLING OF AGRICULTURAL NON-POINT SOURCES POLLUTANTS IN UPPER PANGANI RIVER BASIN (UPRB), TANZANIA
}

\author{
Mwanuzi Fredrick, \\ University of Dar es salaam Box 35131 \\ Dar es Salaam, Tanzania fmwanuzi@yahoo.com Box 35131
}

\begin{abstract}
The Upper Pangani River and its watershed are increasingly being impacted by environmental problems which include non point source pollutants that are threatening the watershed resources. Increased human activities due to population increase, and hence agricultural activities, livestock development, the use of agrochemicals and other land development in the basin, have tended to lead to a serious pollution of the river water which also affects not only the aquatic life but also human health.

With intensive and extensive modern agriculture in which artificial fertilizers are in frequent use, there is a high probability to find chemicals easily flowing into water, thus polluting it. The introduction of agricultural chemicals in rivers may be detrimental. Nitrogen and Phosphorus which are present in agricultural chemicals are essential plant nutrients, which when introduced into surface waters may cause some health problems such as blue-baby syndrome and stomach cancer.

To carry out this study we divided the Upper Pangani River basin into two sub-basins; Kikuletwa and Ruvu. The study concentrated on Ruvu sub-basin to study and model the pollution transported to the rivers. QUAL2E model was chosen and applied to assess the pollution status of the river network. The model simulated stream flow, dissolved oxygen, phosphorus and nitrogen compounds. From model results, the amount of non-point source load reaching Ruvu river was found to be 7857.81tons/yr for nitrogen and 12057.39 tons/yr for phosphorus. The results of the QUAL2E model suggest that there is pollution at upstream rivers as a result of application of fertilizers to the irrigation schemes which are the main sources of non point source pollution.
\end{abstract}

Key Words: Non-point source, Pangani river, Irrigation, Nutrients, QULA2E model

\section{INTRODUCTION}

Pangani river basin is located in the Northeast of Tanzania, is one of the most important basin for extraction of natural resources in Tanzania. The basin covers an area of about $43,650 \mathrm{~km}^{2}$, most of it is in Tanzania with approximately $3914 \mathrm{~km}^{2}$ in Kenya. (Figure 1). In Tanzania, the basin is spread over four administrative regions: Kilimanjaro, Arusha, Manyara and Tanga.

The Pangani river has two main tributaries: the Ruvu, whose tributaries begin on the Eastern slopes of Mt. Kilimanjaro; and the Kikuletwa, whose tributaries begin on Mt. Meru and the Southern slopes of Mt. Kilimanjaro. Mount Kilimanjaro bounds the river basin in the Northeast and the Meru mountain in the Northwest. In the east lies Pare and Usambara mountains, while the dry Maasai plain is in the South-west part of the catchment.

At the confluence of the Ruvu and Kikuletwa rivers lays the Nyumba ya Mungu Reservoir. The effluent of the reservoir is known as the Pangani river which flows for $432 \mathrm{~km}$ and joined by Mkomazi river far downstream before emptying into the Indian Ocean. (Figure 1). 


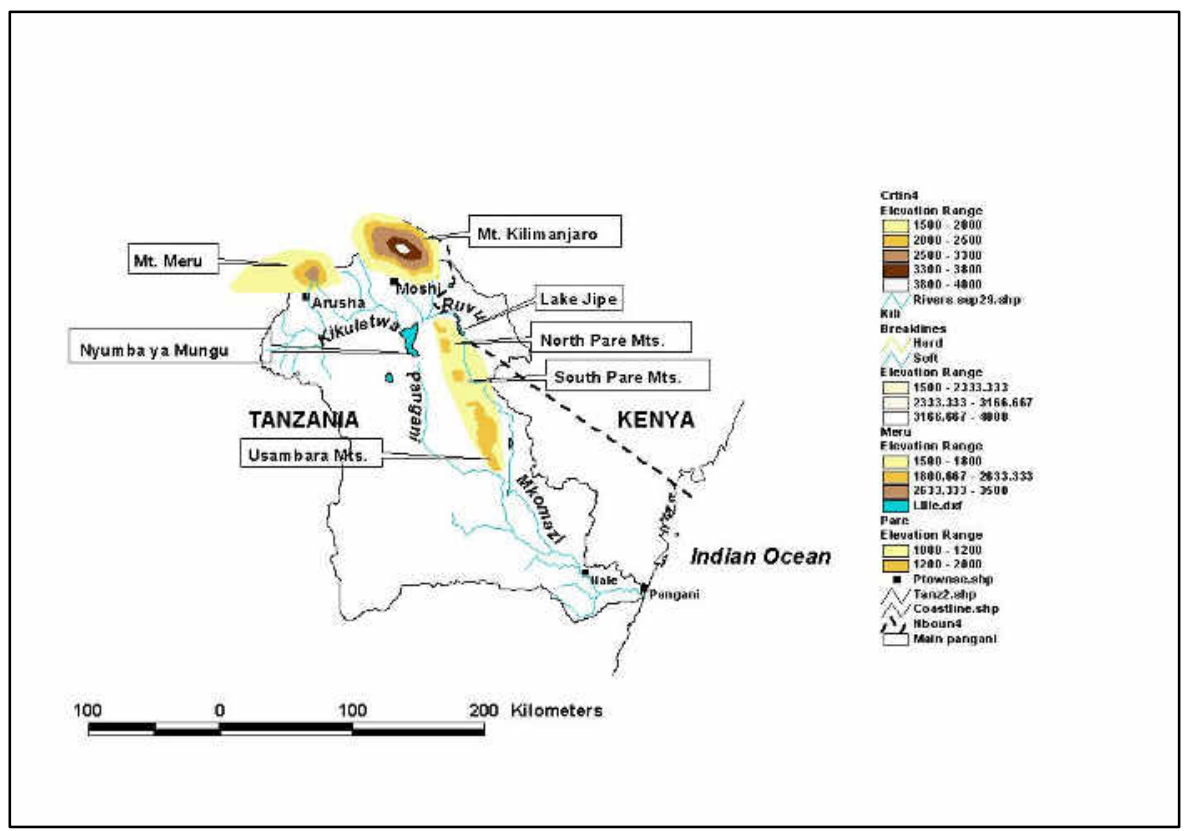

Figure 1. Pangani River Basin

The study area covers the upstream of Nyumba ya Mungu reservoir in the Pangani basin. The catchment of Nyumba ya Mungu dam forms the upper part of the Pangani basin (Upper Pangani basin) which is located between latitude $3^{0} 00^{\prime} 00^{\prime}$ " and $4^{0} 3{ }^{\prime} 50^{\prime}$ ' South, and longitude $36^{\circ} 20^{\prime} 00^{\prime}$ ' and $38^{0} 00^{\prime} 00^{\prime \prime}$ 'East.

The water in the Upper Pangani basin and its small river branches is used for irrigation, domestic purposes, small scale industry and also for hydropower generation. There are an estimated 3.7 million people in the Pangani river basin, $80 \%$ of whom rely either directly or indirectly, on agriculture for their livelihoods. $90 \%$ of the basin's population live in its upper parts. This settlement concentration yields population density of up to 300 people per $\mathrm{km}^{2}$, and each household farmed an average area of 10.4 ha (Lein, 2002). These data indicate and imply an intensive use of the land for agriculture to sustain the crowded population, to situation which may lead to an environmental degradation. Rapid environmental degradation of Pangani basin on the other hand is mainly caused by disposal of rapidly increasing industrial, agricultural and domestic wastes. Industrial pollution and agricultural pollution contribute to river pollution, as well as everyday activities that drain untreated pollutants and leachate into rivers and streams.

\section{MATERIALS ANA METHODS}

\section{Data gauging stations}

The seven gauging stations and the Kivulini irrigation scheme in upper pangani river basin as shown in figure 2 were established as part of an overall water quality monitoring exercise to monitor water quality in the catchment. Water samples for the water quality data in upper Pangani river basin were collected on monthly basis from the seven sites. The samples were collected using the grab method of sample collection. The samples bottles were labelled with the date, time and site number or gauging station name. The samples were then analysed for the water quality data which included nitrate concentration, ammonia concentration, phosphate concentration and dissolved oxygen concentration. 


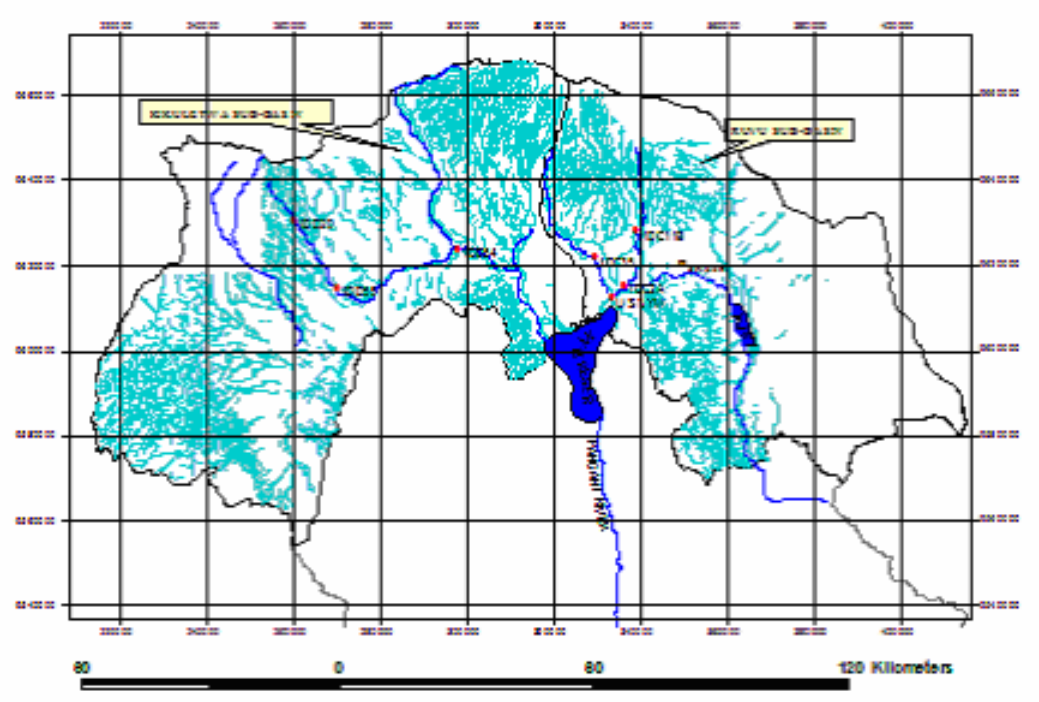

Figure 2. Locations of gauging stations in UPRB

\section{DATA COLLECTION}

The data collection included the determination of the available gauging stations including the station names, code numbers, river name where the station is located and the locations in terms of latitude and longitude of each station as well as the time series data and meteorological data. The time series data collected were discharge (river flow) data and the water quality data. The meteorological data were collected from the Ministry of Water and Livestock Development at Ubungo - Dar es salaam, University of Dar es salaam department of Water Resources Engineering database and also from previous studies. The meteorological data collected were rainfall data and climatic data. The climatic data include mean relative humidity, mean temperature and mean evaporation. Other data used in creating and defining the model structure and parameters are derived principally from spatial analysis of basin characteristics and previous studies. Spatial data analyzed for model construction was the land use data. The Kivulini irrigation scheme data (which were taken at the point of discharge in Ruvu river) was collected from the Ministry of Agriculture and Livestock and other data collected from the previous studies included the amount of artificial fertilizers applied to irrigation schemes in UPRB.

\section{NON-POINT SOURCE POLLUTION (NPS)}

Non point source pollution is an introduction of impurities into a surface water body or an aquifer, usually through a non-direct route and from sources that are diffuse in nature. Discharges from non-point sources are usually intermittent, associated with a rainfall; and they occur less frequently and for shorter periods of time than do point source discharges. As the runoff moves, it picks up and carries away natural and human-made pollutants, finally depositing them into lakes, rivers and even the underground sources of drinking water. The potential for pollution of surface waters increases when flows resulting from irrigation or rainfall come from land that has received untreated human or animal waste or when irrigation water contains animal manure. The four major forms of NPS pollution are: sediments, nutrients, toxic substances and pathogens as were briefly explained. byGiorgini and Zingales, 1986.

\section{AGRICULTURAL ACTIVITIES IN PANGANI RIVER BASIN}

Agriculture is a major activity taking place in upper Pangani river basin. More than $50 \%$ of the basin receives only $50 \mathrm{~mm}-600 \mathrm{~mm}$ of rainfall per year, making conditions for agricultural productions by rainfed difficult as thus irrigation farming has been a traditional practice in the Pangani basin for generations due to rainfall uncertainties. More than $80 \%$ of the water available in Pangani basin is used for irrigation activities. Irrigation is the artificial application of water to the soil, other than natural precipitation, for the purpose of crop production

There are 2000 traditional furrows in the Pangani basin being used for irrigation and water supply. Traditional irrigation furrows are highly inefficient, and may loose as much as $85 \%$ of water between the point of abstraction and its destination. (Mujwahuzi, 2001). There are also large scale irrigation projects 
operating; the largest farms are sugar estates owned by TPC and lower Moshi rice farm owned by Kilimanjaro Agricultural Development Programme (KADP). According to the Kilimanjaro regional agricultural office, the amount of artificial fertilizers applied per year are as tabulated in Table 1 below. Table 2 shows the distributed fertilizers in Arusha region. (Mng'agi, 2000). These tables indicate the extent of use of artificial fertilizers in the regions where the river crosses.

Table 1: Artificial Fertilizers used in Kilimanjaro region

\begin{tabular}{|l|l|}
\hline TYPE OF FERTILIZERS & AMOUNT OF FERTILIZERS USED (In tones) \\
\hline S.A (Sulphate of Ammonium) & 500 \\
\hline N.P.K 20:10:10 (Nitrogen Phosphorus Potassium) & 400 \\
\hline N.P.K 6:20:18 (Nitrogen Phosphorus Potassium) & 210 \\
\hline C.A.N (Calcium of Ammonium Nitrates) & 160 \\
\hline UREA (Ammonium Nitrates) & 1000 \\
\hline D.A.P (Diammonium Phosphorus Potassium) & 100 \\
\hline T.S.P (Tripple Super Phosphate) & 75 \\
\hline
\end{tabular}

Table 2: Distributed Fertilizers in Arusha region

\begin{tabular}{|l|l|l|l|}
\hline $\begin{array}{l}\text { TYPE OF } \\
\text { FERTILIZERS }\end{array}$ & $\begin{array}{l}\text { DEMAND } \\
\text { (tones) }\end{array}$ & $\begin{array}{l}\text { AVAILABILITY } \\
\text { (tones) }\end{array}$ & $\begin{array}{l}\text { DISTRIBUTED } \\
\text { (tones) }\end{array}$ \\
\hline SA 21\% & 1500 & 850 & 680 \\
\hline CAN 26\% & 700 & 385 & 275 \\
\hline UREA 46\% & 6200 & 3500 & 2400 \\
\hline NPK 20:10:10 & 1200 & 850 & 650 \\
\hline NPK 6:20:18 & 700 & 480 & 450 \\
\hline DAP 45\% & 400 & 540 & 320 \\
\hline TSP 26\% & 300 & 255 & 125 \\
\hline TOTAL & 11000 & 6860 & 4900 \\
\hline
\end{tabular}

\section{MOVEMENT AND DISTRIBUTION OF POLLUTANTS (NITROGEN AND PHOSPHORUS) FROM AGRICULTURAL LAND TO SURFACE WATERS}

Pollutants can exist in water in different states. They can be dissolved or they can be in suspension, which means that they exist in the form of droplets or particles. Pollutants can also be dissolved in droplets or absorbed by particles. All states of pollutants can travel great distances through water in many different ways. Particulate matter may fall to the bottom of streams and rivers or rise to the surface, depending on its density. This means that it mostly remains on the same location when the water does not flow very fast. In rivers, pollutants usually travel great distances. The distance they travel depends upon the stability and physical state of the pollutant and the speed of flow of the river. Pollutants can travel farthest when they are in solution in a river that is fast flowing. The concentrations on one site are then generally low, but the pollutant can be detected on many more sites than when it would not have been so easily transported. (Susanna and Wenli, 2002). Pollutant movement are then simulated using a computer package QUAL2E

\section{DESCRIPTION OF QUAL2E MODEL}

The enhanced stream water quality model (QUAL2E) is a steady state model for conventional pollutants in branching streams and well-mixed 
lakes. The model is applicable to dendritic streams that are well mixed. It assumes that the major transport mechanisms, advection and dispersion, are significant only along the main direction of flow (the longitudinal axis of the stream). The model

$$
\frac{\partial c}{\partial t}=-v \frac{\partial c}{\partial x}+D \frac{\partial^{2} c}{\partial x^{2}} \pm R
$$

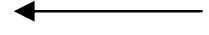

Where $\mathrm{v}$ is the advection coefficient and $\mathrm{D}$ is the dispersion coefficient and $\mathrm{R}$ is the reaction coefficient.

For data entry in QUAL2E, the river system is divided into reaches which are river portions containing an integer number of computational elements having constant hydraulic characteristics, that is Manning's roughness coefficient, dispersive coefficient and geometric properties and for each computational element within a reach, a hydrologic balance in terms of stream flow (e.g. $\mathrm{m}^{3} / \mathrm{s}$ ), a heat balance in terms of temperature (e.g. ${ }^{0} \mathrm{C}$ ), and a material balance in terms of concentration (e.g. $\mathrm{mg} / \mathrm{l}$ ) are written. Hydraulic data, reaction rate coefficients, initial conditions, and incremental flows data are constant for all computational elements within a reach. solves the one-dimensional (equation 1) steady state advection dispersion equation using an implicit finite difference technique. (Brown and Barnwell Jr., 1987)

\section{(1) Advection-dispersion equation}

QUAL2E can be operated either as a steady state or dynamic model, making it a very helpful water quality planning tool. When operated as a steady state model, it can be used to study the impact of waste loads (magnitude, quality, and location) on instream water quality. By operating the model dynamically, the user can study the effects of diurnal variations in meteorological data on water quality (primarily DO and temperature) and also can study diurnal DO variations due to algal growth and respiration. The program simulates changes in flow conditions along the stream by computing a series of steady state water surface profiles.The model concept of the interactions between nutrient cycles, algae production, benthic oxygen demand, carbonaceous oxygen uptake, atmospheric aeration and their effect on the behaviour of DO is schematically shown in figure 3 .

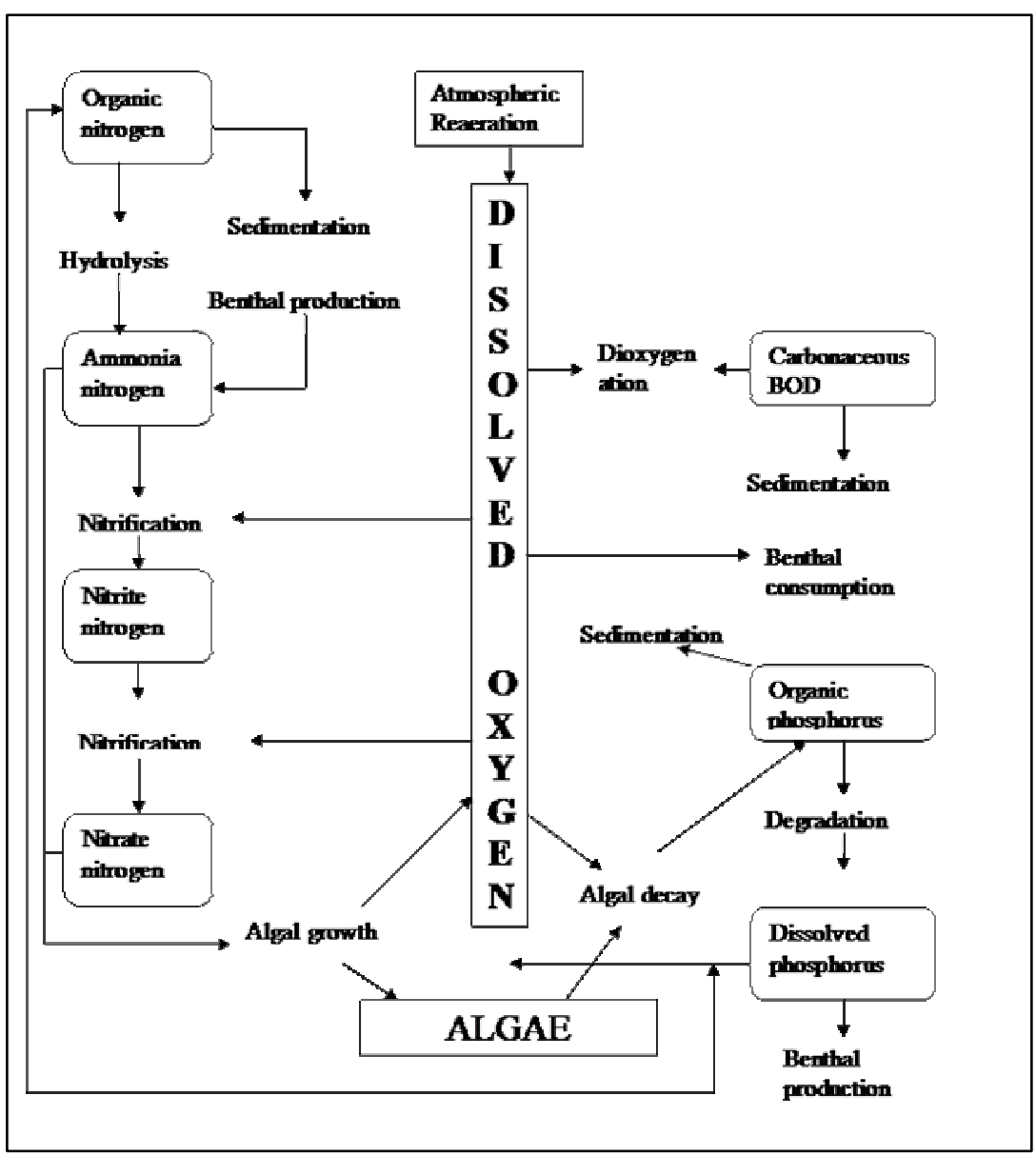

Figure 3: Major constituent interactions in QUAL2E model 


\section{QUAL2E Model application}

The modeling software QUAL2E has been applied to Ruvu sub-basin to assess the amount of pollution loads and the impact on water quality in upper pangani river basin. The data used for this model are the long term averages which imply that the daily variations have already been taken care of (steady state situation). All the parameters are the field observed values from the respective streams as shown in Table 4The waste load into the river is also assumed to be continuous. Figure 4 shows the river network and locations of sampling points in Pangani river basin. In Figures 5 and 6 a comparison of nutrients in the upper and lower parts of pangani river is shown. The lower upper part is more polluted due to agricultural activities.

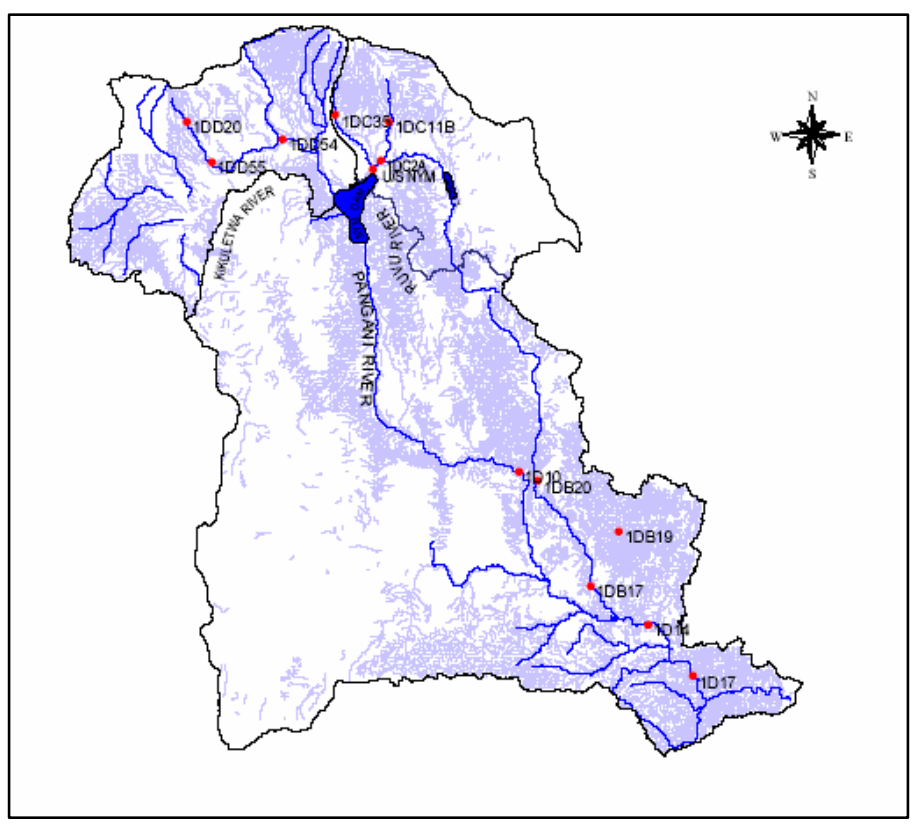

Figure 4 River network and locations of sampling points in Pangani river basin.

Table 4: Average Values of Water Quality Data to Ruvu Sub-Basin at Different Stations

\begin{tabular}{|l|l|l|l|l|l|}
\hline $\begin{array}{l}\text { STATION } \\
\text { NAME }\end{array}$ & $\begin{array}{l}\text { PHOSPHATE } \\
(\mathrm{mg} / \mathrm{l})\end{array}$ & $\begin{array}{l}\text { NITRATE } \\
(\mathrm{mg} / \mathrm{l})\end{array}$ & $\begin{array}{l}\text { AMMONIA } \\
(\mathrm{mg} / \mathrm{l})\end{array}$ & $\begin{array}{l}\text { DO } \\
(\mathrm{mg} / \mathrm{l})\end{array}$ & $\begin{array}{l}\text { FLOW } \\
\left(\mathrm{m}^{3} / \mathrm{s}\right)\end{array}$ \\
\hline 1DC35 & 22.57 & 6.05 & 0.3 & 7.83 & 1.59 \\
\hline 1DC11B & 46.75 & 29.53 & 0.58 & 3.87 & 1.95 \\
\hline 1DC2A & 50.61 & 32.93 & 0.61 & 2.86 & 6.41 \\
\hline U/S NYM & 39.13 & 24.74 & 0.56 & 4.17 & 26.1 \\
\hline KIVULINI & 66.54 & 40.58 & 0.74 & 2.37 & 3.85 \\
\hline
\end{tabular}

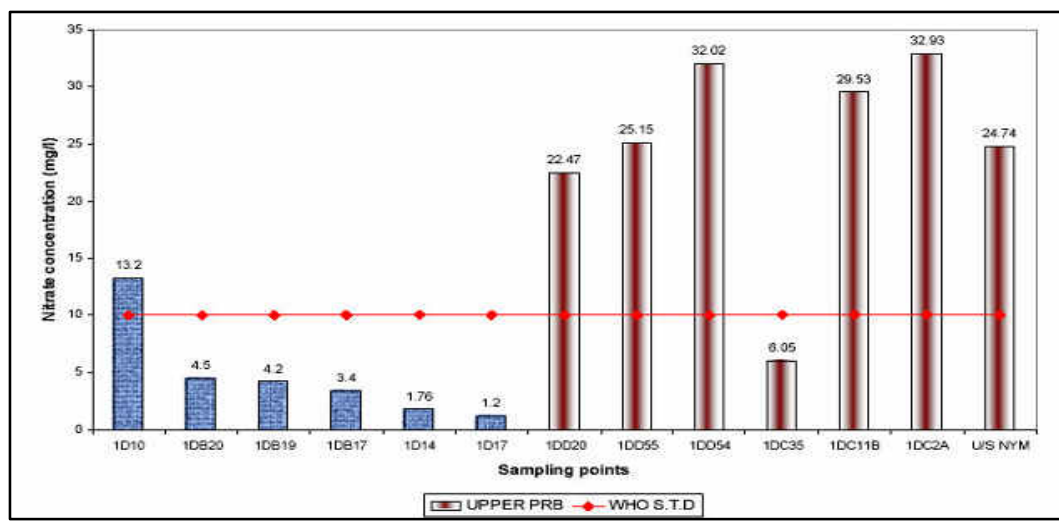

Figure 5. Nitrate concentration in the Upper and Lower Pangani River 


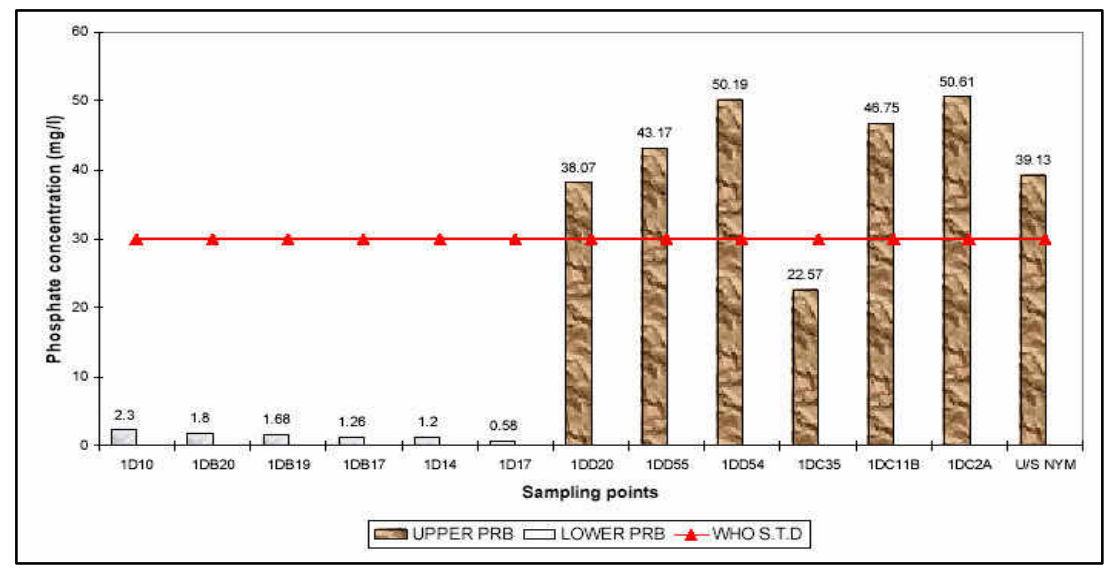

Figure 6. Phosphate concentration in the Upper and Lower Pangani River

\section{RESULTS AND DISCUSION}

\section{MODEL RESULTS}

The simulation included the delivery of pollution loads from upstream rivers including Kivulini irrigation scheme to Ruvu River. The in stream simulation of nutrients requires information about Dissolved Oxygen (DO) since its concentrations affect the extent of chemical reactions involving nutrients such as nitrification. Dissolved oxygen must be simulated in order to simulate nutrient transport and transformations in the stream. The simulation of DO included the effects of air and water temperature, reaeration and algal activity (photosynthesis and respiration).

The model was also used to simulate other water quality parameters such as nitrate, ammonia and phosphate. The QUAL2E model input parameters which were obtained in annual basis along Ruvu River are summarized in table 5.

Table 5: Observed parameters (Water Quality Data) along Ruvu River

\begin{tabular}{|c|c|c|c|c|}
\hline \multirow[t]{2}{*}{ PARAMETER (mg/l) } & \multicolumn{4}{|c|}{ DISTANCE (KM) } \\
\hline & 0 (U/S Point) & 21 & 37 & 48 \\
\hline Nitrate $(\mathrm{mg} / \mathrm{l})$ & 20.87 & 40.58 & 32.93 & 14.74 \\
\hline Ammonia (mg/l) & 0.65 & 0.74 & 0.51 & 0.26 \\
\hline Phosphate (mg/l) & 32.6 & 66.54 & 50.61 & 29.13 \\
\hline Flow $(\mathrm{m} 3 / \mathrm{s})$ & 0.61 & 3.85 & 6.41 & 26.1 \\
\hline DO (mg/l) & 6.28 & 2.37 & 2.86 & 4.17 \\
\hline
\end{tabular}

The water quality and the river flow simulation results of the QUAL2E model are explained in detail in the following figures which show the variation of water quality data due to river flow and waste load input from upstream rivers as well as the Kivulini irrigation scheme. River flow can bring changes to water quality parameters concentration due to dilution effect where the concentration of nutrients tend to decrease. Model Calibration was done by the trial method, fitting the parameters (reaction coefficient values) to give the best fit for the plotted simulated and observed values. The simulation results are shown in Figures 7 to 11 . Figure 7 shown river flows whereby the river flow increase from upstream to downstream of Ruvu river due to other rivers that are discharging into Ruvu river which hence increase its quantity of flow.
From QUAL2E simulation, the amounts of pollutant concentrations along Ruvu River are estimated to be as follows:

- Nitrate concentrations range from $9.13 \mathrm{mg} / \mathrm{l}$ to $37.85 \mathrm{mg} / \mathrm{l}$.

- Ammonia concentrations range from $0.04 \mathrm{mg} / \mathrm{l}$ to $0.65 \mathrm{mg} / \mathrm{l}$.

- Phosphate concentrations range from $15.53 \mathrm{mg} / \mathrm{l}$ to $61.83 \mathrm{mg} / \mathrm{l}$.

For all the above water quality parameters, the highest concentration were observed immediately after $21 \mathrm{Km}$ which represents discharge from Kivulini irrigation scheme.

Figure 8 shows DO simulation results of QUAL2E water quality model along Ruvu River. At $21 \mathrm{Km}$, there is a sudden drop of DO due to higher amounts 
of waste loads from the Kivulini irrigation scheme up to a point (at $37 \mathrm{Km}$ ) where DO concentration increases and becomes even higher at $48 \mathrm{Km}$. This is because river flow increases as you go downstream Ruvu river due to the entry of other upstream rivers where dilution takes place. From the point at $37 \mathrm{Km}$, DO concentrations kept on increasing downstream due to the dilution effect as more upstream rivers (Himo and Njoro) are discharging to the main river (Ruvu river).

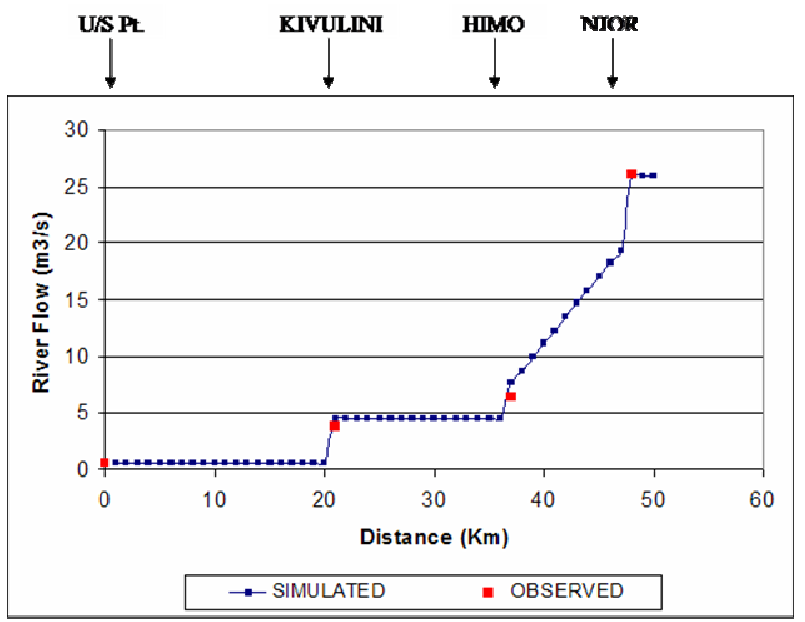

Figure 7. Observed and Simulated Flow

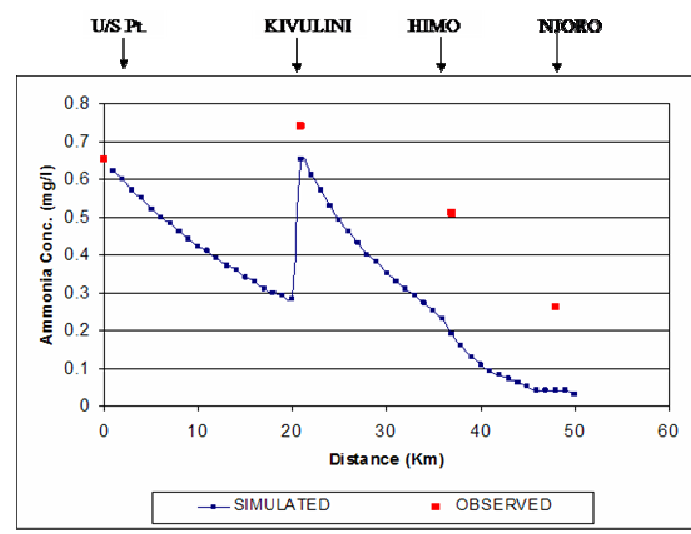

Figure 9: Observed and Simulated Ammonia Concentration along Ruvu River

From figures 9, 10 and 11; the pollutant concentrations of ammonia, nitrate and phosphate seem to be higher at $21 \mathrm{Km}$, and this might be due to the input coming from the Kivulini irrigation scheme which is the main source of nitrogen and phosphorus. From that point, the pollution trend tend to decrease due to the increase of dilution water flow downstream as a result of dilution effect where two river tributaries (Himo and Njoro) are entering the main river.The results indicated that $\mathrm{NO}_{3}, \mathrm{NH}_{3}$ and $\mathrm{PO}_{4}$ concentrations for points closer to the farm (Kivulini irrigation scheme) were higher than those at the point furthest from the farm. (See figures 9 to 11)

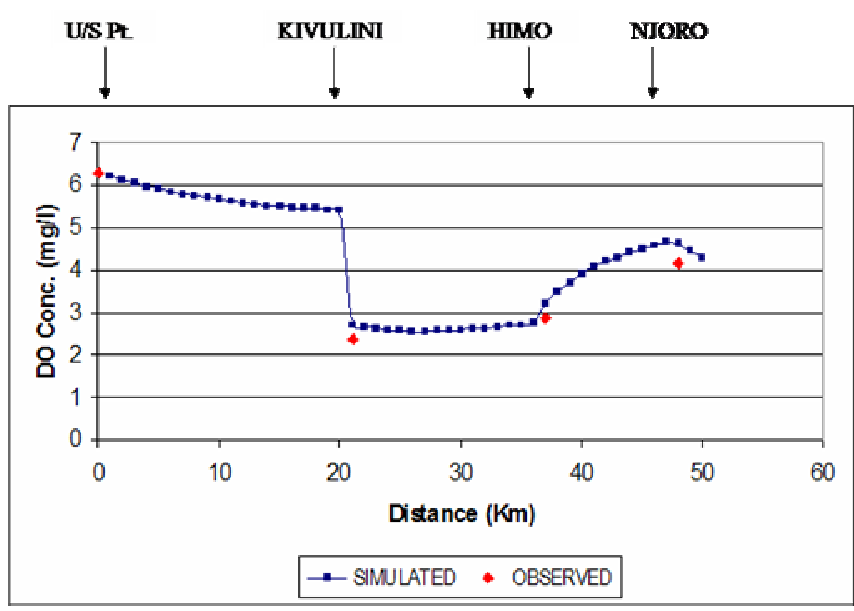

Figure 8. Observed and Simulated Dissolved Oxygen Concentration along Ruvu River

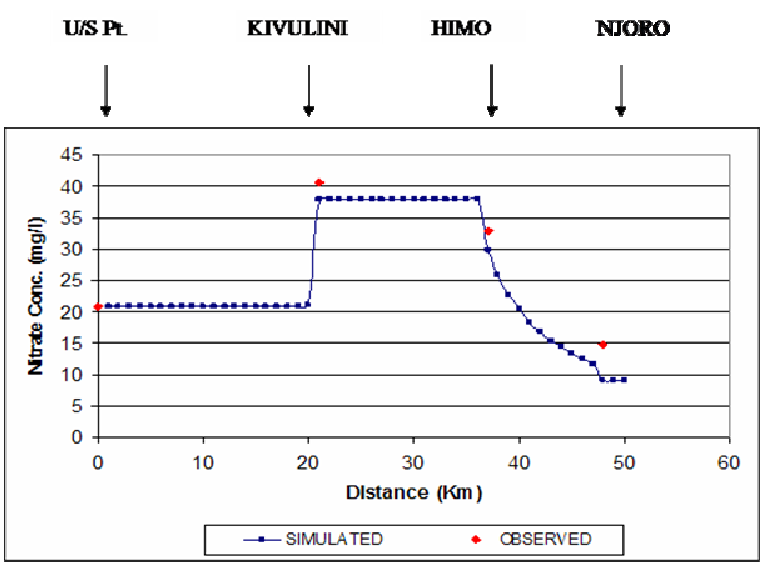

Figure 10: Observed and Simulated Nitrate Concentration along Ruvu River

The spatial variability of DO along Ruvu river reveal that, at U/S pt. DO seem to be higher and decrease with distance farther downstream up to a point (at $21 \mathrm{Km}$ ) where the point source loads from the irrigation scheme are discharged. From that point, DO start to increase up to $48 \mathrm{Km}$. The reason for this trend is that, at $21 \mathrm{Km}$ pollution load is estimated to be higher than other two points (at $37 \mathrm{Km}$ and $48 \mathrm{Km}$ ) where pollution load concentrations decrease as the result of two tributaries (Himo and Njoro) discharging into Ruvu river. There is higher pollution levels at $21 \mathrm{Km}$, $37 \mathrm{Km}$ and $48 \mathrm{Km}$ than at U/S point and thus higher DO is estimated at upstream point than other downstream points. The pollutant concentrations of Nitrate, Ammonia and Phosphate increase with 
distance up to a point (at $21 \mathrm{Km}$ ). From that point, the pollution trend seem to decrease due to changes in flow conditions where the flow increases downstream due to other river tributaries (Himo and Njoro) discharging into Ruvu river.

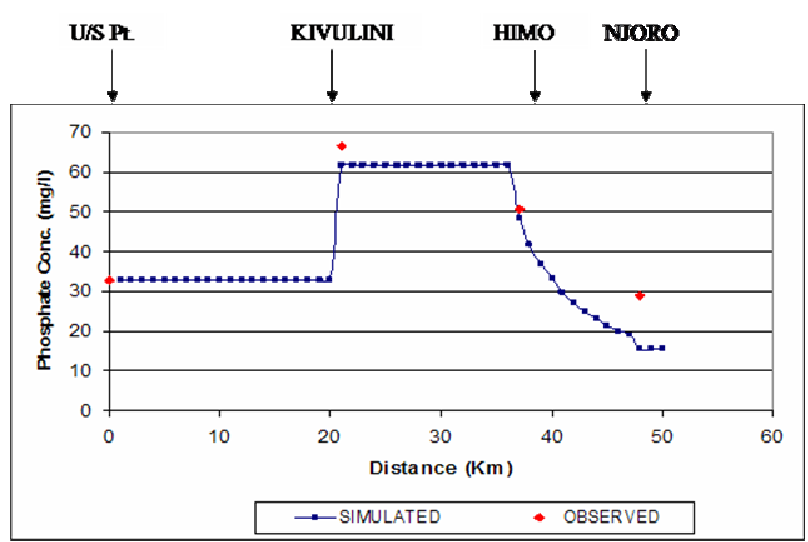

Figure 11 Observed and Simulated Phosphate Concentration along Ruvu River

\section{POINT LOAD CALCULATION}

Table 2.1: The degree of pollution removed by surface and sub-surface runoff from a basin area cannot be directly measured, unlike the pollution from point sources since non-point sources are diffuse in nature. Thus all the methods for evaluation of nutrient load from non-point pollution sources are more or less indirect. (Jakub, 1999). The QUAL2E simulation results for total nitrogen and phosphorus are as shown in the Table 6 below.

\section{Table 2.1:}

Table 6: QUAL2E Simulation Results for Total Nitrogen and Phosphorus

\begin{tabular}{|l|l|l|l|}
\hline LOCATION & $\begin{array}{l}\mathrm{N} \\
(\mathrm{mg} / \mathrm{l})\end{array}$ & $\begin{array}{l}\mathrm{P} \\
(\mathrm{mg} / \mathrm{l})\end{array}$ & $\begin{array}{l}\mathrm{Q} \\
\left(\mathrm{m}^{3} / \mathrm{s}\right)\end{array}$ \\
\hline $\begin{array}{l}\text { Table 2.1: Upstream } \\
\text { point }\end{array}$ & 21.52 & 32.61 & 0.61 \\
\hline At $21 \mathrm{Km}$ & 38.57 & 61.83 & 4.46 \\
\hline At $37 \mathrm{Km}$ & 18.62 & 29.60 & 13.50 \\
\hline At $48 \mathrm{Km}$ & 9.28 & 15.53 & 25.90 \\
\hline
\end{tabular}

By using the QUAL2E simulation results shown in Table 6, the values of point loads were then computed and the results are shown in Table 7.
Table 7: Nutrient Loads for Ruvu Sub-basin in Upper Pangani River Basin

\begin{tabular}{|l|l|l|}
\hline \multirow{2}{*}{ LOCATION } & \multicolumn{2}{|c|}{ NUTRIENT LOAD (ton/yr) } \\
\cline { 2 - 3 } & NITROGEN & PHOSPHORUS \\
\hline $\begin{array}{l}\text { Upstream } \\
\text { point }\end{array}$ & 414.05 & 627.24 \\
\hline At $21 \mathrm{Km}$ & 5424.63 & 8695.98 \\
\hline At $37 \mathrm{Km}$ & 7925.8 & 12602.63 \\
\hline At $48 \mathrm{Km}$ & 7579.74 & 12684.63 \\
\hline
\end{tabular}

From the upstream point to the next point load there is an incremental increase in pollution load. This increase in load must be due to diffuse load (Nonpoint Load) as shown in Table 8.

Table 8: Non-Point Source Load Quantification

\begin{tabular}{|l|l|l|}
\hline LOCATION & NITROGEN & PHOSPHORUS \\
\hline $\begin{array}{l}\mathrm{U} / \mathrm{S}-21 \\
\mathrm{Km}\end{array}$ & 5010.58 & 8068.74 \\
\hline $\begin{array}{l}21 \mathrm{Km} \text { to } 37 \\
\mathrm{Km}\end{array}$ & 2501.17 & 3906.65 \\
\hline $\begin{array}{l}37 \mathrm{Km} \text { to } 48 \\
\mathrm{Km}\end{array}$ & -346.06 & 82 \\
\hline $\begin{array}{l}\text { Total NPS } \\
\text { Load } \\
\text { (tons/yr) }\end{array}$ & 7857.81 & Table 2.1: 12057.39 \\
\hline
\end{tabular}

\section{MODEL TESTING}

The method used for model testing was the Linear Regression Analysis. Regression analysis estimates the relationship between variables whereby a trendline is added. A trendline is most reliable when its R-Squared value (an indicator from 0 to 1 that reveals how closely the estimated values for the trendline correspond to the actual data) is at or near 1.

The model was thus tested by the method of linear regression analysis technique using estimated parameters of nitrate, ammonia and phosphate as shown in figures 12, 13, 14 and produced good model efficiencies as shown in table 9 below:

Table 9: Summary of the results obtained by QUAL2E model along Ruvu River

\begin{tabular}{|l|l|l|l|l||l|}
\hline \multirow{2}{*}{ PARAMETER (MG/L) } & \multicolumn{4}{|c||}{ MODEL EFFICIENCY, $\mathrm{R}^{2}$ (\%) } \\
\cline { 2 - 6 } & $\mathbf{0}($ At U/S Pt.) & $\mathbf{2 1}$ & $\mathbf{3 7}$ & $\mathbf{4 8}$ & \\
\hline Nitrate $(\mathrm{mg} / \mathrm{l})$ & 20.87 & 37.85 & 29.87 & 9.13 & 99.41 \\
\hline Ammonia $(\mathrm{mg} / \mathrm{l})$ & 0.62 & 0.65 & 0.19 & 0.04 & 92.96 \\
\hline Phosphate (mg/l) & 32.6 & 61.83 & 48.32 & 15.53 & 99.69 \\
\hline
\end{tabular}




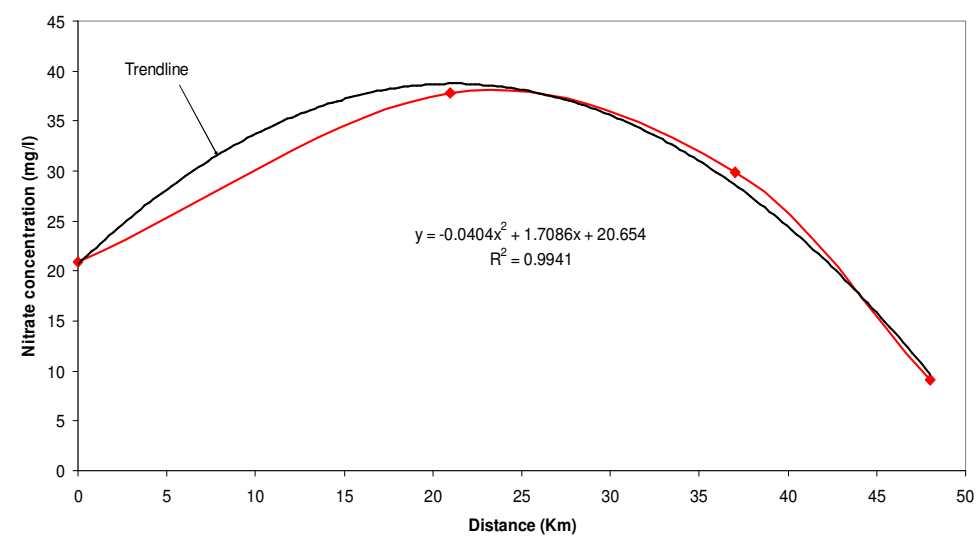

Figure 12: Plot of Nitrate along Ruvu River

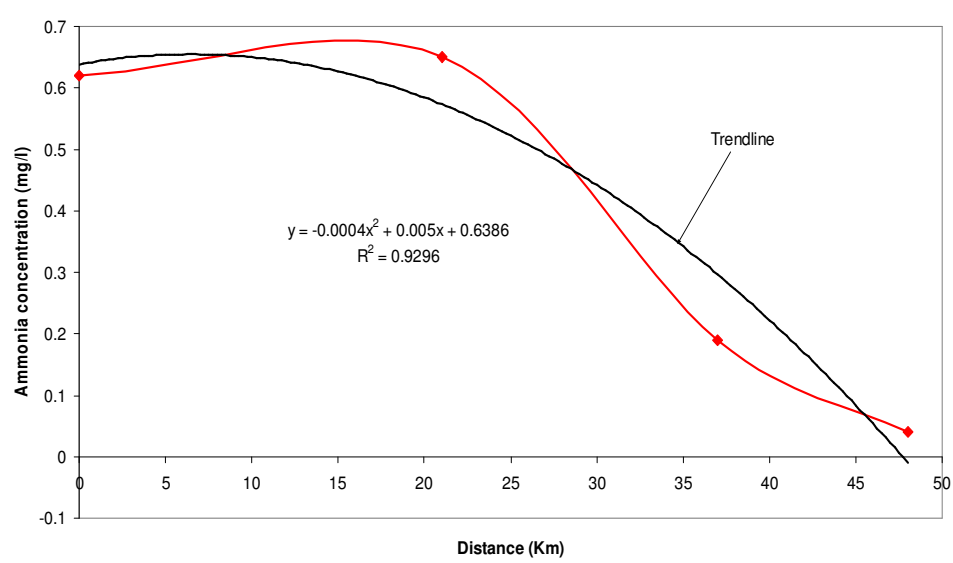

Figure 13: Plot of Ammonia along Ruvu River

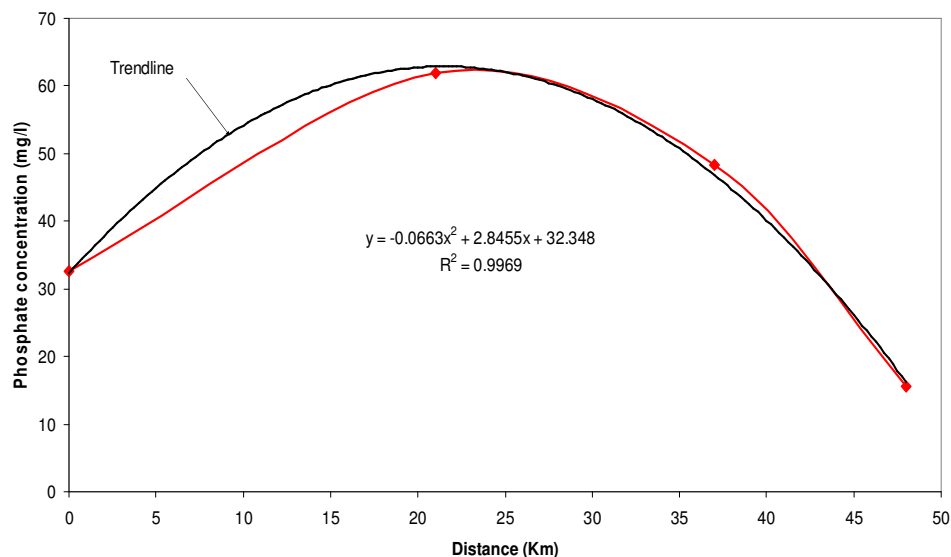

Figure 14: Plot of Phosphate along Ruvu River

\section{CONCLUSIONS}

From the study the following conclusions can be drawn;

- A significant amount of pollution load was observed to originate from land use and irrigation practices into the Ruvu River while Kivulini was established to be one of the potential sources of pollution in Ruvu sub basin.
- QUAL2E is an appropriate model for simulation of water quality at the UPRB with more than $90 \%$ model efficiency.

- The QUAL2E simulation results revealed that, there is more pollution contributed by agricultural nutrients; Nitrogen and Phosphorus in upper pangani river basin since the concentration of nutrients were found to lie above WHO standards. 
- From the results, the amount of non-point source load reaching Ruvu river is found to be

7857.81 tons/yr for nitrogen and 12057.39 tons/yr for phosphorus.

- Furthermore the results have revealed that, the variation of concentration of parameters in river is governed by the distance from the pollution sources, the quality of other rivers that are discharging into the main river and also the quantity of water in the river. This can help the basin manager to know the quality of water at any given location/place.

\section{REFERENCES}

Giorgini, A., and Zingales. F., (1986). Agricultural Non-point sources pollution: Model Selection and Application, Elsevier, Newyork.

Jakub, L., (1999). Evaluation of the Non-Point Sources of Pollution of Surface Water. Department of Physical Geography, Charles University. Czech Republic.

Lein, H., (2002). "Migration irrigation and land-use changes in the lowlands of Kilimanjaro, Tanzania." In Ngana, J.O. (ed.) Water
Resources Management: The case of Pangani River Basin, Issues and Approaches. Dar es salaam, University Press: $28-38$.

Brown, L. C., and Barnwell, T.O.Jr., (1987). The enhanced stream water quality models QUAL2E \& QUAL2E - UNCAS. EPA United States of America.

Mng'agi, R.Y., (2000). Assessment of Pollution Sources in Pangani River Basin Upstream of Nyumba ya Mungu Reservoir. MSc Dissertation, Department of Water Resources Engineering, University of Dar es salaam.

Mujwahuzi, M.R., (2001). Water Use Conflicts in the Pangani Basin. In Ngana J.O. (ed.). Water Resources Management in the Pangani River Basin: Challenges and Opportunities. Dar es salaam, Dar es salaam University Press: $128-137$.

Susanna, T.Y. T., and Wenli, C., (2002). Modelling the Relationship between Landuse and Surface Water Quality. University of Cincinnati, U.S.A. 